\title{
Kazimirus, Dei gracia rex Poloniae etc. Rozważania o wielkości ostatniego Piasta na polskim tronie
}

Ozdobiony królewską koroną, państwem i narodem od Boga sobie powierzonym po męsku i pożytecznie rządził. Albowiem wedle słów proroka miłował pokój, prawdę i sprawiedliwość. Był bowiem najtroskliwszym opiekunem i obrońcą dobrych i sprawiedliwych; złych zaś, rozbójników, gwałtowników i potwarców bardzo srogim prześladowcą ${ }^{1}$

Jan z Czarnkowa o królu Kazimierzu

Kazimierz Wielki. Ostatni król Polski z dynastii Piastów. Znany chyba wszystkim Polakom. Wymieniany jako jeden z najwybitniejszych władców naszego kraju, obok księcia Mieszka I, który zainicjował powstanie organizmu państwowego i przyjął chrzest; jego syna Bolesława Chrobrego umacniającego i rozszerzającego patrymonium odziedziczone po swym ojcu; króla Władysława Jagiełły — krzyżackiego pogromcy z grunwaldzkich pól; Jana Sobieskiego, monarchy Rzeczpospolitej, który stanął pod Wiedniem, aby nie dopuścić do tureckiego „potopu”. Bohater niniejszego artykułu jest znany także najmłodszym obywatelom naszej ojczyzny, bowiem jawi się im jako spokojny i roztropny król, twórca ładu w Królestwie Polskim, i postrzegany jest zapewne jako stary, zadumany, o siwych włosach i takiejż brodzie, dumny lecz nie zadufany, wzór cnót władcy, niczym Karol Wielki. Wszyscy znamy go jako tego, który „Polskę zastał glinianą, drewnianą i brudną, zostawił murowaną"2. Jaka rzeczywiście jest prawda o najwybitniejszym polskim władcy, który w ogóle mógł na krakowskim tronie nie zasiąść, czy to za sprawą poważnej choroby, która spadła na niego ok. 1327 r., czy też mógł polec na polu bitewnym, w trakcie wojen ojca? W niniejszym artykule chciałbym

1 Kronika Janka z Czarnkowa, red. i tłum. A. Bielowski, [w:] Monumenta Poloniae Historica, t. 2, Lwów 1907 [dalej: Janko z Czarnkowa], s. 2-3.

2 Jan Długosz, Roczniki, czyli kroniki słynnego Królestwa Polskiego, ks. IX (1300-1370), tłum. J. Mrukówna, Warszawa 2009 [dalej: Długosz], s. 443. 
nieco bliżej, acz dość selektywnie, przyjrzeć się kilku wybranym epizodom z życia syna Władysława Łokietka i, jak ująłem to w tytule, zastanowić się, czy słusznie przypisano wielkość polskiemu władcy z XIV stulecia.

Epoka kazimierzowska obrosła pokaźną liczbą opracowań naukowych i popularnych. Tomasz Nowakowski pisał: „Kazimierz Wielki jako jeden z najwybitniejszych władców Polski cieszył się dużym zainteresowaniem historyków"3. Było to związane z jego prawie czterdziestoletnim panowaniem, ale, jak nas uczy historia, długie panowanie wcale nie czyni władcy wielkim, czasami bowiem stanowi okres wegetacji politycznej państwa i prowadzi do jego wewnętrznego załamania. Wracając jednak ad rem - do klasycznych już autorów i ich dzieł zaliczyć możemy m.in. biografię monarchy pióra Jerzego Wyrozumskiego pt. Kazimierz Wielki ${ }^{4}$. Także w pierwszym tomie Dziejów Krakowa ${ }^{5}$, który jest autorstwa wymienionego historyka, o władcy tym przeczytamy sporo. Oswald Balzer poświęca królowi dużo miejsca na kartach swej Genealogii Piastów ${ }^{6}$, szczegółowo przypatrując się datom dziennym z życia króla, a raczej różnicom między nimi w różnych źródłach. Marek Kazimierz Barański w swej pracy pt. Dynastia Piastów w Polsce $e^{7}$ poświęca cały rozdział bohaterowi mojego artykułu, pisze jednak o tym panowaniu na tle innych, mając na uwadze sytuację w kraju, który wówczas nie był trwale zjednoczony, jak się powszechnie sądzi. Jan Dąbrowski nazywa w tytule swej pracy ${ }^{8} \mathrm{Ka}-$ zimierza twórcą Korony Królestwa Polskiego, z czym wiążą się także przemiany doktrynalne, ideologiczne, religijne i sam aspekt odbierania władzy monarszej oraz tego, czym ona była, do czego obligowała i na co pozwalała władcy. W innej zaś przypatruje się rozwojowi polskiej monarchii stanowej, akcentując rolę i dokonania króla Kazimierza ${ }^{9}$. Nie możemy także zapominać o takich autorach jak: Stanisław Sroka, Stanisław Szczur, Feliks Kiryk, Henryk Samsonowicz, Tomasz Nowakowski, a także Michał Rożek czy Paweł Jasienica, którzy zwracali uwagę na panowanie króla Kazimierza i jego czasy, zarówno w uniwersyteckich aulach, jak i popularyzując tę wiedzę innymi drogami.

3 T. Nowakowski, Kazimierz Wielki w dawnej i współczesnej historiografii polskiej, [w:] Kazimierz Wielki i jego państwo, red. J. Maciejewski, T. Nowakowski, Bydgoszcz 2011, s. 67.

4 J. Wyrozumski, Kazimierz Wielki, Wrocław 2004.

5 J. Wyrozumski, Dzieje Krakowa. Kraków do schyłku wieków średnich, t. 1, Kraków 1992.

6 O. Balzer, Genealogia Piastów, Kraków 1895.

7 M. K. Barański, Dynastia Piastów w Polsce, Warszawa 2008.

8 J. Dąbrowski, Kazimierz Wielki. Twórca Korony Królestwa Polskiego, Kraków 2007.

9 J. Dąbrowski, Korona Królestwa Polskiego w XIV wieku, Kraków 2010. 
Chciałbym wspomnieć o zapiskach rocznikarskich i kronikarskich, bez których dzisiaj wiedzielibyśmy jeszcze mniej o tamtych czasach. Jan z Czarnkowa w swej kronice pisał o panowaniu króla, a także sytuacji po jego śmierci. Znał monarchę osobiście, gdyż piastował urząd podkanclerzego w ostatnich latach panowania Kazimierza. Ponadto Kronika katedralna krakowska zawiera istotne informacje o życiu ostatniego piastowskiego monarchy. Na szczególną uwagę, w mojej ocenie, zasługują Roczniki, czyli Kroniki sławnego Królestwa Polskiego autorstwa Jana Długosza. Poświęcił on wiele miejsca w swym dziele Kazimierzowi Wielkiemu, czerpał ze źródeł wcześniejszych, być może z takich, które do dnia dzisiejszego nie zachowały się. O królu pisano także w epokach późniejszych, ale opierano się głównie na dziełach poprzedników, zwłaszcza kanonika krakowskiego - arcybiskupa lwowskiego in spe $e^{10}$. Należy wspomnieć jeszcze o źródłach archeologicznych, które stanowią żywy dowód działalności władcy. Część z nich wznosi się ponad powierzchnię ziemi, relikty innych skryte są pod jej powierzchnią. O zamkach pisał m.in. Leszek Kajzer $^{11}$, katalog zamków kazimierzowskich sporządził Piotr Adam Zaniewski ${ }^{12}$.

Zanim przejdę do zasadniczej części mojej pracy, przedstawię genezę związania osoby króla Kazimierza z przydomkiem magnus. W znanym nam dzisiaj znaczeniu został on po raz pierwszy użyty w Statutach Łaskiego z 1505/1506 r. w następującej formie: „Statuta Magni Casimiri Secundi”"13 - jako jeden z tekstów prawnych, wchodzących w skład tej kodyfikacji. Niewątpliwie słowo to użyte zostało, by wyróżnić władcę i podkreślić jego zasługi. Jednak, moim zdaniem, podstawy takiego twierdzenia możemy znaleźć już w dziele Jana z Czarnkowa, a na pewno u Jana Długosza, który pisał o monarsze w następujący sposób:

Pragnął gorąco wzmocnienia i wzbogacenia ojczyzny i państwa. Uprzejmy i uczciwy [...] Był człowiekiem niezwykle skromnym, toteż dopuszczał do siebie zarówno ubogiego, jak bogatego [...] Dla wszystkich życzliwy [...] z natury pałał taką miłością ojczyzny, że o nic bardziej nie zabiegał jak o to, by jej

10 Wyczerpująco o historiografii polskiej dotyczącej króla Kazimierza można przeczytać w artykule: T. Nowakowski, Kazimierz Wielki..., s. 67-86.

11 L. Kajzer, Zamki i dwory obronne w Polsce centralnej, Warszawa 2004; L. Kajzer, S. Kołodziejski, J. Salm, Leksykon zamków w Polsce, Warszawa 2012.

12 P. A. Zaniewski, Zamki Kazimierza Wielkiego, Kraków 2012.

13 W. Uruszczak, Commune incliti Poloniae regni privilegium constitutionum et indultuum. O tytule i mocy prawnej Statutu Łaskiego z 1506 r., „Zeszyty Naukowe Uniwersytetu Jagiellońskiego. Prace z Prawa Własności Intelektualnej” 2006, z. 96, s. 115-135, http://www.law.uj.edu.pl/users/khpp/statut_laski.htm [dostęp: 27.10.2015]. 
pomóc i zapewnić jej jak najwięcej zaszczytów. [...] Okupując wady zaletami, miał więcej takich cech, które słusznie winny znajdować uznanie, niż tych, które trzeba mu było darować. [...] Był najłagodniejszym wśród współczesnych królów i książąt. Sprawując przez czterdzieści lat rządy w Królestwie Polskim przystępnością i dobrocią zacierał blask królewskiego majestatu. Pałał gorącą chęcią powiększenia i uświetnienia swego państwa i Królestwa Polskiego. Odznaczał się niepospolitą roztropnością, ale przy wznoszeniu budowli był hojny, co przystoi znakomitym władcom. Rządził tak bardzo sprawiedliwie, że w niczym nie uchybiał wzorowi sprawiedliwego władcy ${ }^{14}$.

Moim zdaniem, tak wyjątkowa opinia Długosza o tym właśnie władcy przyczyniła się do utrwalenia szczególnego obrazu panującego wśród potomnych, choć wypominał królowi błędy, pewnych rzeczy nie mógł zrozumieć, inne go oburzały, a jeszcze inne wydawać się mogły niewybaczalne. Pod rokiem 1370 umieszcza swoiste epitafium, stawiając Kazimierza jako wzór idealnego władcy. Nie powinno więc dziwić, że tak utrwalony przez lata pogląd oraz faktyczne dokonania monarchy sprawiły, że mówimy o nim Kazimierz Wielki.

W zasadniczej części niniejszego artykułu chciałbym skupić się na czynach króla Kazimierza prowadzących do jego wielkości i próbie jej udowodnienia. Pierwszą w mym przekonaniu rzeczą, która przyczyniła się do późniejszego określenia Kazimierza mianem „wielkiego” była kwestia uregulowania praw do polskiej korony. W ówczesnych stosunkach międzynarodowych, pomimo królewskiej koronacji Łokietkowego syna w Katedrze Wawelskiej na króla Polski, dokonanej przez arcybiskupa gnieźnieńskiego Janisława, Kazimierz nadal funkcjonował jako król Krakowa, gdyż beneficjentem mającym prawo do tytułu monarchy polskiego był Jan Luksemburski, król Czech ${ }^{15}$. Nie chcąc wdawać się w szczegóły, napomknę jedynie, że powyższa sytuacja spowodowana była polsko-czeską unią personalną, jaka zawiązała się między oboma krajami za panowania ostatnich Przemyślidów, pod koniec XIII i na początku XIV stulecia. Władysław Łokietek nie był w stanie w trakcie swych rządów, jako król Polski, odzyskać pełni praw do tego tytułu, gdyż sama jego koronacja była wynikiem działania dyplomacji zarówno papieskiej, jak i polskiej, bowiem - jak zaznaczył Ojciec Święty Jan XXII - „koronacja musi się odbyć tak, aby niczyje prawa nie zostały naruszone"16.

14 Długosz, s. 444-446.

15 J. Wyrozumski, Kazimierz..., s. 39-40; M. K. Barański, Dynastia..., s. 454.

16 M. K. Barański, Dynastia..., s. 453. Oczywiście oznaczało to, że koronacja nie może odbyć się w Gnieźnie, gdyż byłby to jawny atak na interesy i przeciwko pretensjom wnoszonym przez Jana Luksemburczyka. Istotne jest to, że papież przeciwko samej 
Ojciec Kazimierza był też skonfliktowany z Wacławem II, któremu miał złożyć hołd lenny, czego jednak nie uczynił. Przez to, jak również przez nieudolne rządy w swej części Wielkopolski, zmuszony był salwować się ucieczką przed wyprawą karną czeskiego władcy ${ }^{17}$. Gdy powrócił do kraju, musiał się zmagać $\mathrm{z}$ opozycją $\mathrm{w}$ postaci biskupa krakowskiego Jana Muskaty ${ }^{18}$ czy wójta krakowskiego Alberta ${ }^{19}$. Większą część swego panowania król Władysław poświęcił wojnie, bo do tego zmusiła go sytuacja, w jakiej znalazło się dopiero co zjednoczone królestwo, a raczej mała jego część. Jednak precedens $z$ koronacją na Wawelu sprawił, że (nie uderzając bezpośrednio w króla czeskiego) można było usankcjonować władzę w Polsce. Z punktu widzenia dyplomatycznego i prawnego wykupienie wyłącznych praw do polskiej korony było rzeczą niezwykle istotną, a zarazem prestiżową. Król Kazimierz wiedział o tym doskonale i już w pierwszych latach swego panowania starał się tego dokonać. Po wykorzystaniu różnych metod dyplomatycznych udało się to podczas zjazdu monarszego w Wyszehradzie, w $1335 \mathrm{r}$. Za dwadzieścia tysięcy kop groszy praskich wykupił prawa Jana Luksemburczyka do polskiej korony ${ }^{20}$. W mojej opinii waga tego wydarzenia polegała na prawnym i międzynarodowym umocowaniu Kazimierza jako króla wszystkich ziem polskich, ich pana i dziedzica, a co za tym idzie uzyskaniu przez niego równorzędnej pozycji względem pozostałych europejskich monarchów, w grze dyplomatycznej, mariażach, sojuszach etc. Sam fakt wykupienia owego tytułu byłby niczym, gdyby za słowami i gestami nie szły czyny, a wraz z nimi potęga samego państwa, która wówczas prezentowała się jeszcze bardzo blado.

Przejdę teraz do relacji z państwami ościennymi i polityki prowadzonej wobec nich przez króla Kazimierza, które przyczyniły się do uwznioślenia jego panowania. Państwo, które władca obejmował po swym ojcu Władysławie, liczyło nieco ponad sto tysięcy kilometrów kwadratowych ${ }^{21}$. W jego skład wchodziła Małopolska i Wielkopolska oraz lenna: ziemia łęczycka i ziemia

ceremonii nie miał obiekcji. Najciekawszy jednak, w mojej opinii, jest fakt, że koronacji dokonał arcybiskup gnieźnieński w Katedrze Krakowskiej, łącząc tym samym, symbolicznie obie dzielnice. Miejmy jednak na uwadze, że koronować według Ordo coronandi mógł jedynie arcybiskup, o czym pisze M. Rożek, Polskie koronacje i korony, Kraków 1987, s. 50-61.

17 M. K. Barański, Dynastia..., s. 443.

18 Ibidem, s. 446, 448, 453.

19 Ibidem, s. 449.

20 Ibidem, s. 485; J. Wyrozumski, Kazimierz..., s. 59-60.

21 F. Kiryk, Wielki król i jego następca, Kraków 1992, s. 10. 
sieradzka ${ }^{22}$, którymi władali bratankowie króla Władysława, Przemysł sieradzki ${ }^{23}$ i Władysław Garbaty ${ }^{24}$. Byli oni starsi od nowego króla, a co za tym idzie, nie do końca było pewne, czy złożą mu hołd lenny i podporządkują się tym samym jego rządom. Innym zmartwieniem był Zakon Najświętszej Marii Panny Domu Niemieckiego w Jerozolimie, który okupował Pomorze Gdańskie, ziemię dobrzyńską i Kujawy, z którym trwał rozejm ${ }^{25}$. Królestwo Polskie było w złych stosunkach dyplomatycznych z Brandenburgią oraz Czechami ${ }^{26}$, większość księstw śląskich oraz księstwo płockie uznawało zwierzchnictwo tych drugich ${ }^{27}$. Podobnie sytuacja miała się z Mazowszem, które z powodu ekspansywnej polityki Władysława Łokietka szukało opieki Krzyżaków ${ }^{28}$. Ruś była słaba i nie mogła udzielić wsparcia polskiemu monarsze $^{29}$. Przymierze z pogańską Litwą Giedyminowiczów, zrealizowane dzięki małżeństwu Kazimierza i Aldony Anny ${ }^{30}$, nie było mile widziane w chrześcijańskiej Europie i mogło bardziej zaszkodzić niż przynieść korzyści. Najlepsze relacje i rzeczywista pomoc mogła przyjść z dworu budzińskiego, na którym, jeszcze jako królewicz, przebywał sam Kazimierz ${ }^{31}$. I rzeczywiście, już jako król, w swej polityce zagranicznej wyraźnie korzystał ze wsparcia Królestwa Węgier. Na uwagę zasługuje też fakt dobrych relacji z papieżami Benedyktem XII, Klemensem VI, Innocentym VI, Urbanem V - którzy, będąc de facto francuskimi zakładnikami podczas tzw. niewoli awiniońskiej, wydawali decyzje sprzyjające polskiemu monarsze ${ }^{32}$. Nie sposób oczywiście rozwodzić się nad tymi kwestiami w krótkim artykule i nie jest to moim celem. Chciałbym jedynie zasygnalizować pewne dokonania polskiego władcy, który poprzez przemyślaną i mądrą politykę zagraniczną umocnił królestwo i doprowadził do wzrostu jego znaczenia na arenie międzynarodowej.

Z perspektywy czasu, znając kolejne wydarzenia, które miały miejsce, śmiało można stwierdzić, że prowadził bardzo rozsądną grę dyplomatyczną.

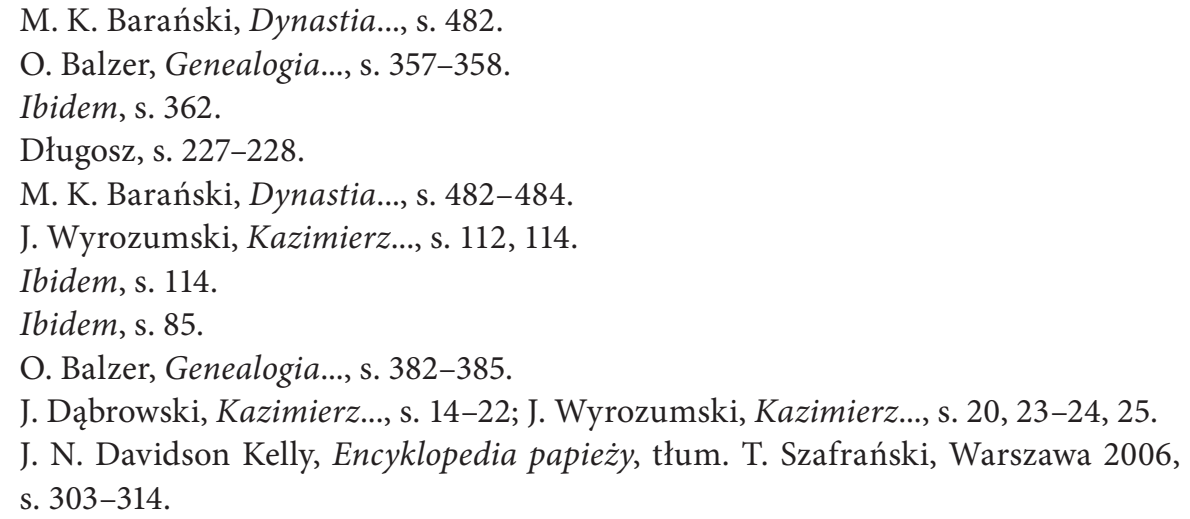


Lawirował pomiędzy sojuszami z Wittelsbachami, Andegawenami, Litwinami etc., by móc szachować to jednych, to drugich ${ }^{33}$. Miał zmysł, poparty odpowiednimi radami najznamienitszych person w Radzie Królewskiej, z kim i kiedy się wiązać, wyczekiwał najdogodniejszego momentu do ataku. Przez całe swe panowanie toczył spory i sądził się z zakonem krzyżackim, zaś arbitrami w tych procesach byli król czeski i węgierski ${ }^{34}$. Supliki słał także do papieży, by ci mediowali i wyrokowali w sprawie spornych dóbr ${ }^{35}$. Mimo niekorzystnego dla Polski wyroku królów oraz przychylnego Benedykta XII, a właściwie komisji działającej z jego pełnomocnictwa, Kazimierzowi nie udało się odzyskać Pomorza Gdańskiego, ziemi chełmińskiej i michałowskiej, za co został bardzo skrytykowany przez Jana Długosza:

A ja nie mogę wystarczająco wyrazić mojej niechęci do króla polskiego Kazimierza, który zaniechał obowiązków wojennych, by z nakładem większych kosztów, ucztować, by się chwalić, że posiada w skarbcu złożoną większą ilość złota, by hołdować znów uciechom żołądka i Wenery, by prowadzić życie bez trudów, osławione z powodu rozkoszy. Lekceważąc nakazy ojca, okazał się bardziej małoduszny i gnuśny w obronie ojczyzny od biskupów i kapłanów, człowiekiem o gorszym charakterze, spragnionym pokoju i oby nie gnuśności. A przecież powinien był przewyższać innych nie tylko odwagą, ale sprytnym postępowaniem i pełnym znoju działaniem. Za krótki okres pokoju, który należało zerwać choćby nazajutrz, gdyby tak przypadek zdarzył, z powodu najmniejszej obrazy, miał zostawić Polakom i swoim następcom, królom polskim długą, trwającą bez przerwy walkę o ziemię pomorską ${ }^{36}$.

Znając kolejne wydarzenia i komfort życia króla, prawie pół wieku później od opisywanych wydarzeń Jan Długosz wysunął nieco pochopne wnioski. Jako duchowny, być może miał też na uwadze konflikt, w jaki popadł Kazimierz z biskupem krakowskim Janem Bodzantą, który wysłał do władcy wikariusza Katedry Wawelskiej Marcina Baryczkę, nie obawiającego się monarchy ${ }^{37}$. Powodem było niemoralne prowadzenie się króla. Kapłan w trakcie dostarczania dekretu ekskomuniki posunął się za daleko, a mianowicie miał prawić Kazimierzowi o karach, jakie Kościół może nałożyć za takie zachowanie. Król ograniczył się jedynie do inwektyw w gniewie pod adresem

\footnotetext{
M. K. Barański, Dynastia..., s. 483-492.

J. Dąbrowski, Kazimierz..., s. 26-29.

J. N. Davidson Kelly, Encyklopedia..., s. 306.

Długosz, s. 285.

37 Ibidem, s. 323.
} 
wikariusza ${ }^{38}$. Wedle słów Jana Długosza, Kazimierz nakazał zabicie Marcina Baryczki za namową i pod wpływem dworzan, którzy utopili kapłana nocą w Wiśle, w dzień św. Łucji, tj. 13 grudnia 1349 r. ${ }^{39}$ Podobną relację w swej kronice przytacza Jan z Czarnkowa ${ }^{40}$. Na uwagę zasługuje fakt, że mimo podniesienia ręki na duchownego, króla nie spotkała żadna kara, jedynie miał ufundować w formie ekspiacji świątynie np. w Wiślicy, Sandomierzu i Niepołomicach. Interesujące jest również to, że w przeciwieństwie do innych duchownych-męczenników (np. św. Stanisław, św. Tomasz Becket, św. Jan Nepomucen), którzy zostali zabici z polecenia władcy, kult Marcina Baryczki miał raczej niewielkie znaczenie, może właśnie ze względu na to, że wiązał się z osobą króla Kazimierza, tego, którego potomni ochrzcili przydomkiem „wielki”. A może monarcha został ukarany za swój czyn surowiej niż ktokolwiek inny? Wszakże nie doczekał się nigdy syna-królewicza ${ }^{41}$.

Wracając jednak do meritum, Długosz zdawał sobie sprawę z działań podejmowanych przez Kazimierza i potrafił je ze sobą logicznie powiązać, jednak w kwestii krzyżackiej, w mojej opinii, postąpił ahistorycznie. Król zdawał sobie sprawę, w jakiej kondycji jest jego armia, wiedział, że nie pokona nią Krzyżaków, a ponadto nie mógł przewidzieć reakcji państw ościennych na ewentualny polski najazd na zakon. W latach czterdziestych XIV w. jego uwagę przyciągała Ruś i walka o schedę po Bolesławie Jerzym II Trojdenowiczu, który zginął w niejasnych okolicznościach ${ }^{42}$. Kwestie te łączą się ze sobą bardzo ściśle, a ponadto okres walk o Ruś zbiega się z wojną o Śląsk oraz negocjacjami z Krzyżakami. W obliczu możliwości wybuchu wojny aż na trzech frontach, król musiał działać zdecydowanie i szybko rozwiązywać problemy oraz utworzyć pewną gradację spraw najważniejszych. Sytuacja na północy Polski prezentowała się nieciekawie. Krzyżacy byli w posiadaniu części dawnych ziem korony polskiej, która nie była w stanie siłą odebrać ich nieprzyjacielowi. W obliczu swego rodzaju pata, który nastał po nieudanych arbitrażach, w Kaliszu, w 1343 r., pomiędzy Polską a państwem krzyżackim zawarto pokój, w myśl którego Korona odzyskała Kujawy i ziemię

38 Ibidem.

39 Ibidem, s. 323-324.

40 Janko z Czarnkowa, s. 5.

41 Szerzej o relacjach Króla z Kościołem, zwłaszcza o nieszczęsnym Marcinie Baryczce, ale także o ogólnym wizerunku Kazimierza w oczach Jana Długosza pisze J. Sperka, Obraz Kazimierza Wielkiego w „Rocznikach” Jana Długosza, „Rocznik Niepołomicki” 2010, t. 2, s. 241-267.

42 Najprawdopodobniej został otruty przez bojarów - vide J. Wyrozumski, Kazimierz..., s. 86 . 
dobrzyńską, zaś zakon (przez zrzeczenie się praw króla polskiego do Pomorza Gdańskiego, ziemi chełmińskiej i michałowskiej) otrzymał właśnie te tereny ${ }^{43}$. W obliczu zagrożenia, praktycznie $z$ każdej strony polskiego królestwa, pokój ten musiał zostać zawarty, a w przypadku zmiany sytuacji międzynarodowej, koniunktury etc. mógł zostać zrewidowany siłą, jak to niejednokrotnie w historii miało miejsce. Być może wizyta króla Kazimierza w 1366 r. w Malborku ${ }^{44}$ była pewną próbą zbadania od wewnątrz potencjału pozostającego w dyspozycji państwa zakonnego. Najwyraźniej wypadła ona niekorzystnie, gdyż nigdy później monarcha nie zapędził się w te rejony. Ustabilizowanie granicy na północy umożliwiło królowi wyprawy na Ruśs ${ }^{45}$ i zmagania z Tatarami, Litwinami, Rusinami w latach 1340-1348 i 13491366. Kazimierz dał jakoby priorytet kierunkowi wschodniemu. Podbijając te tereny, uzyskałby dostęp do lądowych i morskich szlaków handlowych nad Morzem Czarnym. Być może miało to zwrócić uwagę książąt śląskich, którzy woleliby handlować z tymi obszarami przez Polskę, niźli wybrać kierunek handlu na południe, przez Czechy. Chciał też szerzyć tam katolicyzm, tępiąc przy tym dominujące prawosławie ${ }^{46}$. Korona poszerzyła się o tereny Rusi Halickiej, Włodzimierskiej i Podola ${ }^{47}$. Jak wspomniałem wcześniej, lata czterdzieste to także wojna śląska, którą rozpoczął w 1345 r. najazd Jana Luksemburczyka na włości księcia świdnickiego Bolka II Małego ${ }^{48}$, sprzymierzeńca Polski, Węgier i cesarza Ludwika IV Bawarskiego. Podczas wojny oblegany był Kraków ${ }^{49}$. Z sojuszniczych obowiązków nie wywiązywali się Wittelsbachowie. Mimo to Czesi w końcu ustąpili. Zawarto rozejm, pokoju jednak nie podpisano. W 1346 i kolejnym roku żadna ze stron nie atakowała, co było spowodowane wewnętrznymi problemami Rzeszy, a mianowicie papieską detronizacją Ludwika Bawarskiego ${ }^{50}$, wyborem Karola Luksemburczyka na cesarza oraz śmiercią Jana Luksemburczyka - 26 sierpnia 1346 r., w bitwie pod Crécy ${ }^{51}$. W październiku kolejnego roku zmarł cesarz Ludwik, którego

43 Ibidem, s. 76-77.

44 A. Gąsiorowski, Itinerarium króla Kazimierza Wielkiego. Materiały 1333-1370, „Roczniki Historyczne” 1998, t. 64, s. 175-208.

45 J. Wyrozumski, Kazimierz..., s. 78-111.

46 K. Stopka, A. K. Banach, J. Dybiec, Dzieje Uniwersytetu Jagiellońskiego, Kraków 2000, s. 13.

47 J. Dąbrowski, Kazimierz..., s. 31-32, 35-39.

48 M. K. Barański, Dynastia..., s. 494.

49 Ibidem, s. 494-495.

50 Ibidem, s. 495.

51 Ibidem. 
na tronie zastąpił Karol ${ }^{52}$, co wyklarowało sytuację. Nowy władca wystawił dokument, w którym inkorporował Śląsk i Łużyce do Królestwa Czech, bez jakiegokolwiek wyszczególnienia, co godziło w niezależność księstwa świdnicko-jaworskiego, nie zmieniając przy tym stanu posiadania w tym rejonie Europy. Kazimierz zaatakował, by zademonstrować siłę swej armii jeszcze przed negocjacjami pokojowymi, które sfinalizowane zostały zawarciem pokoju namysłowskiego w $1348 \mathrm{r}^{53}$, do którego dążyły obie strony, gdyż polskiego monarchę bardziej interesował kierunek wschodni, zaś cesarza i władcę czeskiego - sprawy niemieckie. Poza deklaracją wzajemnej przyjaźni i miłości, nie wprowadzono żadnych zmian terytorialnych. Karol IV uznał polskie roszczenia wobec Krzyżaków i Brandenburgii oraz deklarował pomoc w odzyskaniu utraconych ziem, Kazimierz zaś miał nie sprzymierzać się z wrogami cesarstwa. Istotnym elementem pokoju, akcentowanym w historiografii, była kwestia niezrzeczenia się przez polskiego monarchę praw do Śląska.

Kończąc analizę polityki zagranicznej króla, chciałbym uwzględnić Królestwo Węgier, z którym - jak już wspominałem - Polska miała najlepsze relacje. Spowodowane to było sojuszem zawiązanym jeszcze przez ojca Kazimierza, a utwierdzone małżeństwem węgierskiego monarchy Karola Roberta oraz córki Władysława Łokietka, Elżbiety, w 1320 r. ${ }^{54}$ Sojusz z Polską okazał się dla francuskiej dynastii władającej Węgrami jeszcze bardziej lukratywny, gdy polski królewicz Kazimierz zachorował, pod koniec lat dwudziestych XIV w., a Władysław Łokietek obiecał Andegawenom polski tron ${ }^{55}$. Oczywiście podyktowane to było szczególnymi okolicznościami, bowiem Królestwo potrzebowało sojusznika przeciwko otaczającym je wrogom, w tym zwłaszcza Luksemburgom, propozycja ta mogła również spowodować umorzenie długów. Łokietek nie chciał, by państwo po raz kolejny uległo rozbiciu ${ }^{56}$. Podobnie uczynił jego syn, król Kazimierz, który powierzał tron wawelski władcom węgierskim ${ }^{57}$. Obietnice te dały Polsce silnego sojusznika, niezwykle bogatego i liczącego się na europejskiej scenie politycznej. Węgrzy wsparli także kazimierzowską wyprawę na Ruś. Zastanawiające jest tylko jedno. Dlaczego polski monarcha tak szybko, bo już w pierwszych latach swego panowania, mając zaledwie dwadzieścia parę lat postanawia użyć takiego argumentu w rozgrywce dyplomatycznej? Czy był pewny tego, że

\footnotetext{
Ibidem.

Ibidem, s. 497.

J. Wyrozumski, Kazimierz..., s. 39.

Ibidem, s. 226-227.

56 Ibidem, s. 223-245.

57 Ibidem.
} 
spłodzi syna, właśnie z uwagi na to, że był jurnym, pełnym wigoru młodym człowiekiem? I że obietnica złożona węgierskiemu monarsze okaże się pełna fruktów jedynie dla Polski? Czy uważał, że uda mu się w jakiś inny sposób, np. w piastowskiej dynastii, znaleźć kogoś godnego tego miana i spróbować wyrugować później Ludwika? Pytania te muszą pozostać bez odpowiedzi. W moim przekonaniu, król Kazimierz stosował tu bardzo przemyślaną politykę. Z jednej strony potrzebował sojusznika i partnera, a takim Królestwo Węgier z pewnością było i za tak intratną ofertę mogło wiele zaoferować. $\mathrm{Z}$ drugiej strony może rzeczywiście widział w królu węgierskim, w razie swej bezpotomnej śmierci, odpowiedniego kandydata na tron polski, wiedząc, jak dobrze dynastia Andegawenów rządziła na Węgrzech.

Co do Mazowsza, które u progu panowania Kazimierza raczej niechętnie traktowało Królestwo Polskie, a ponadto było związane stosunkami lennymi z Czechami, trzeba stwierdzić, że pod koniec jego rządów zwróciło się ku Koronie i od niej uzależniło. Król rozwiązał tę kwestię niezwykle mądrze. Użył siły, by zdobyć Księstwo Płockie, lecz następnie porozumiał się z mazowieckimi książętami, zawarł z nimi traktaty i przyjął od nich hołd. Były to lata pięćdziesiąte, ataki litewskie były na porządku dziennym i właśnie ta okoliczność przemawiała najsilniej do książąt mazowieckich za związaniem się z Koroną. Kolejnym majstersztykiem w grze dyplomatycznej polskiego króla było jego zachowanie po bezpotomnej śmierci Kazimierza I warszawskiego. Mógł jako senior zająć jego ziemie, lecz wolał przekazać je bratu zmarłego, Siemowitowi III i przyjąć od niego hołd ${ }^{58}$. Posunięcie to udowadnia, jak zdolnym był dyplomatą. Z pewnością zasięgał rady doradców, jednak ostateczne decyzje podejmował samodzielnie. W tej sytuacji zamydlił nieco oczy książętom mazowieckim, nie przejmując ich domen, co naraziłoby go na nieprzychylne opinie ze strony miejscowej arystokracji i innych panujących, ale i tak osiągnął swoje cele. Zdawał sobie sprawę, że Czechy leżą zbyt daleko, by egzekwować swe prawa, a Mazowszanie lękają się Litwinów i być może Krzyżaków.

Rekapitulując dokonania polskiego władcy na arenie międzynarodowej, jawią nam one ostatniego przedstawiciela królewskiej dynastii Piastów jako roztropnego monarchę, który podejmował słuszne i korzystne dla Polski decyzje. Znał swoje możliwości i wiedział, „gdzie sięgnąć nie może”. Był realistą, niepozbawionym przy tym fantazji. Jednocześnie nie byłby król Kazimierz tak wielkim władcą, gdyby nie prowadzona przez niego polityka wewnętrzna, zarządzanie i administrowanie państwem, jego rozwój. Zacznę od reformy sił zbrojnych.

58 J. Dąbrowski, Kazimierz..., s. 40. 
Główną siłę uderzeniową armii miała stanowić konnica, złożona ze szlachty, dobrze wyszkolona i wyekwipowana. Władca wprowadził system chorągiewny ${ }^{59}$. Dzieląc wojsko na oddziały, ułatwił wydawanie im rozkazów i kierowanie do konkretnych zadań. Ponadto zarządził, że miast mieli bronić wszyscy ich mieszkańcy, a także wszyscy ci, którzy żyli w pobliżu. Na czele armii stawał sam król ${ }^{60}$. Po raz pierwszy za panowania Kazimierza Wielkiego pojawiła się artyleria ${ }^{61}$. Sprawą najważniejszą, jeśli chodzi o kwestie wojskowe, była gruntowna przebudowa starych fortyfikacji i budowa nowych. Zbudował ponad pięćdziesiąt zamków i dworów, a prawie trzydzieści miast otoczył murami. Rozbudował Zamek na Wawelu. Oddajmy ponownie głos Janowi Długoszowi, który podszedł do sprawy detalicznie:

On też po raz pierwszy [uświetnił] zamek krakowski wspaniałymi budowlami, komnatami, wieżami i fosami, rzeźbami, malowidłami i dachami. Wybudował też połączone z Krakowem miasto Kazimierz, również miasta, twierdze i grody: Wieliczkę, Skawinę, Olkusz, Będzin, Lelów, Sandomierz, Wiślicę, Szydłów, Radom, Opoczno, Wąwolnicę, Lublin, Kalisz, Pyzdry, Stawiszyn, Wieluń, Konin, Piotrków, Łęczycę, Płock, Inowłódź, Lwów, Sanok, Krosno i Czchów. Także zamki i dwory: w Poznaniu, Kaliszu, Sandomierzu, Lublinie, Lwowie (górny i dolny), w Pyzdrach, Sieradzu, Wieluniu, Łęczycy, Kole, Płocku, Niepołomicach, Szydłowie, Przedborzu, Brzeźnicy, Bolesław$\mathrm{cu}$, Ostrzeszowie, Przemyślu, Lanckoronie, Będzinie, Lelowie, Czorsztynie, Oćcu, Krzepicach, Sieciechowie, Solcu, Zawichoście, Nowym Mieście zwanym Korczynem, Koninie, Nakle, Wieluniu, Międzyrzeczu, Kruszwicy, Złotorii, Przedeczu, Bydgoszczy, Lubaczowie, Trembowli, Haliczu, Tustaniu, Opocznie, Szydłowie, Przyszowie, Rawie i Wyszogrodzie ${ }^{62}$.

Budował także liczne świątynie. W czasie jego panowania Polska obrosła w liczne gotyckie budowle.

Analizując zasługi Kazimierza Wielkiego, na koniec pozostawiłem słynną kodyfikację praw, a mianowicie statuty wiślicko-piotrkowskie. Wydanie odrębnych zbiorów praw dla Małopolski i Wielkopolski, jak wskazuje Juliusz Bardach, symbolizowało różnice między prowincjami ${ }^{63}$. Historycy

\footnotetext{
M. K. Barański, Dynastia..., s. 535.

Ibidem.

1 Ibidem.

62 Długosz, s. 441-442.

63 J. Bardach, B. Leśnodorski, M. Pietrzak, Historia ustroju i prawa polskiego, Warszawa 2001, s. 87.
} 
prawa podkreślają, że była to pierwsza taka kodyfikacja w Polsce, a jedyna za panowania dynastii Piastów o tak szerokim zakresie i obszarze, który obejmowała. Warto podkreślić, że statuty kazimierzowskie odchodziły od obowiązującego wówczas prawa zwyczajowego, jednak opierały się bardzo silnie na nim. Większość z nich dotyczyła prawa karnego, znalazły się też takie dotyczące Korony. Niestety, ich oryginalna wersja nie dotrwała do naszych czasów. Na tej kodyfikacji opierali się następcy Kazimierza Wielkiego na polskim tronie, wydając stosowne dokumenty: ekstrawaganty, prejudykaty i petyta ${ }^{64}$. Statuty miały za zadanie ujednolicenie rozstrzygnięć w podobnych kwestiach w całym państwie, a ponadto były opoką dla szlachty, która widziała w nich obronę przed nadużyciami ze strony urzędników.

Na uwagę zasługuje też fakt utworzenia na zamku krakowskim „Ius supremum Magdeburgense castri Cracoviensis" ${ }^{35}$. Była to instytucja apelacyjna, uniezależniająca poddanych króla polskiego od wyroków sądu magdeburskiego, stanowiąca o samodzielności i roztropności Kazimierza. Ponadto spod jurysdykcji prawa niemieckiego król wyjął także Żydów, opierając się na statucie kaliskim Bolesława Pobożnego. Odtąd mieli być oni sądzeni przez sądy królewskie.

Nie sposób pominąć jeszcze jednego istotnego dokonania króla Kazimierza, które w nieco zmienionej postaci przetrwało do dnia dzisiejszego. Mowa tu oczywiście o Studium Generale ${ }^{66}$. Jego powstanie związane było z potrzebą posiadania dobrze wyedukowanej kadry urzędniczej, która mogłaby pracować na królewskim dworze. Jak pisze Jerzy Wyrozumski: „Powstanie uniwersytetu krakowskiego przypisać należy niewątpliwie rozsądkowi politycznemu, zapobiegawczości i dalekowzroczności Kazimierza Wielkiego [...]"67. Potwierdzeniem tych słów niech będzie pewna nadinterpretacja rzeczywistości przez monarchę, który w suplice do papieża napisał, że do innej wszechnicy jest czterdzieści dni drogi ${ }^{68}$, dodając też, że wysyłani tam „szlachetni klerycy" ${ }^{69}$ często padają ofiarami bandytów. Uniwersytet w Krakowie powstał 12 maja $1364 \mathrm{r}^{70}$, chociaż król rozpoczął starania o zgodę na fundację studium już w latach pięćdziesiątych ${ }^{71}$. Fundacyjny przywilej

\footnotetext{
Ibidem, s. 88.

5 Sąd Wyższy Prawa Niemieckiego na zamku w Krakowie.

6 Długosz, s. 386-388.

67 J. Wyrozumski, Kazimierz..., s. 217.

68 Ibidem, s. 218.

69 Ibidem.

70 Ibidem; F. Kiryk, Nauk przemożnych perła, Kraków 1986, s. 57; K. Stopka, A. K. Banach, J. Dybiec, Dzieje Uniwersytetu Jagiellońskiego..., s. 11.

71 F. Kiryk, Nauk przemożnych perła, s. 54.
} 
kazimierzowski rozpoczynał się od słynnych słów: „Niechże tam będzie nauk przemożnych perła [...]"72. Wzorowany na Uniwersytecie w Bolonii, miał trzy wydziały, niestety bez prestiżowej teologii ${ }^{73}$. Śmierć króla w $1370 \mathrm{r}$. i brak zainteresowania ze strony andegaweńskiego monarchy spowodowały, że uczelnia, de facto, przestała działać. Jej odrodzenie i obecna nazwa są związane z królową Jadwigą oraz jej mężem, królem Władysławem Jagiełłą.

Zasług Kazimierza Wielkiego było znacznie więcej, trudno je w tak krótkim tekście wymienić, poza tym nie to było moim celem. Chciałem w sposób aforystyczny ująć na kilku stronach dokonania najwybitniejszego polskiego władcy, nie omijając również jego ludzkich słabości. Wskazać, że pomimo tych paru niechlubnych kwestii, został uznany przez potomnych za godnego nadanego przydomka i jedynego w polskiej historiografii „Wielkiego” monarchę in facto. W mojej opinii, Kazimierz Wielki zaiste wybitnym królem był. Świadczą o tym przytoczone dowody i myśli zawarte w dziełach wybitnych naukowców, które starałem się sumiennie przytaczać. Sytuacja, w jakiej zastał Polskę ostatni $z$ dynastii Piastów władca sugerowałaby, że próżno liczyć na istotną zmianę. Jednak umiejętne wykorzystanie realiów, intelekt oraz zdolności sprawiły, że król mógł wyprowadzić Koronę z lokalnych podziałów i okiełznać sytuację zewnętrzną. Niestety, nie pozostawił po sobie dziedzica, który mógłby przejąć po nim tron na Wawelu i kontynuować „królewski szczep Pastowy". Postanowił jednak oddalić widmo kolejnych podziałów i wewnętrznych wojen, przekazując koronę swemu szwagrowi Ludwikowi.

Jako że był człowiekiem, zdarzało mu się grzeszyć, błądzić i ulegać pokusie. Jego życie obfitowało w miłostki. Lubił ucztować, był łakomy oraz podniósł rękę na Kościół. To jedyne wady, które można przypisać Kazimierzowi. Być może są to cechy, z którymi kojarzymy pewnych władców i tylko z nimi, a jeszcze inni zostaliby wyklęci i potępieni za zbrodnie przeciwko Bogu na jego sługach. Król swym zachowaniem i postępowaniem wyjednał sobie łaski, by zyskać miłość u poddanych i przychylność wśród kleru. Kwestią niezwykle dyskusyjną jest „oddanie” północnych ziem Krzyżakom. Wedle mojej opinii, król potwierdził niejako status quo. Skupiał się w swej polityce na osiągalnych celach, odwodząc imaginację na plan dalszy i nie tracąc czasu na nonsensowne spory.

Konkludując uznałem, że mijająca w zeszłym roku 645 rocznica śmierci króla będzie dobrą okazją, by raz jeszcze przyjrzeć się postaci najwybitniejszego polskiego władcy i przypomnieć, choć w małym stopniu, za co Kazimierz uzyskał przydomek - Wielki.

72 J. Wyrozumski, Kazimierz..., s. 218.

73 F. Kiryk, Nauk przemożnych perła, s. 57. 


\section{Bibliografia}

\section{Źródła}

BALZER O., Statuty Kazimierza Wielkiego, Poznań 1947.

DŁUGOSZ J., Roczniki, czyli kroniki stynnego Królestwa Polskiego, księga dziewiąta 1300-1370, tłum. J. Mrukówna, Warszawa 2009.

Kronika Janka z Czarnkowa, wyd. i tłum. A. Bielowski, [w:] Monumenta Poloniae Historica, t. 2, Lwów 1907.

\section{Opracowania}

BALZER O., Genealogia Piastów, Kraków 1895.

BARAŃSKI M. K., Dynastia Piastów w Polsce, Warszawa 2008.

BARDACH J., LEŚNODORSKI B., PIETRZAK M., Historia ustroju i prawa polskiego, Warszawa 2001.

DAVIDSON KELLY J. N., Encyklopedia papieży, tłum. T. Szafrański, Warszawa 2006.

DĄBROWSKI J., Kazimierz Wielki. Twórca Korony Królestwa Polskiego, Kraków 2007.

DĄBROWSKI J., Korona Królestwa Polskiego w XIV wieku, Kraków 2010.

FABIAŃSKI M., Złoty Kraków, Kraków 2010.

GĄSIOROWSKI A., Długoszowe itineraria królewskie, „Roczniki Historyczne” 1970, t. 36, s. 109-126.

GĄSIOROWSKI A., Itinerarium króla Kazimierza Wielkiego. Materiały 13331370, „Roczniki Historyczne” 1998, t. 64, s. 175-208.

GĄSIOROWSKI A., Nad itinerarium Kazimierza Wielkiego, „Kwartalnik Historyczny" 1979, t. 86, s. 733-740.

GĄSIOROWSKI A., Podróże panującego w średniowiecznej Polsce, „Czasopismo Prawno-Historyczne" 1973, t. 25, z. 2, s. 41-68.

JAGLARZ M. (red.), Kazimierz Wielki - historia i tradycja, „Rocznik Niepołomicki" 2010, t. 2.

JASIENICA P., Polska Piastów, Warszawa 2007.

JASIŃSKI K., Rodowód Piastów małopolskich i kujawskich, Poznań-Wrocław 2001.

JASIŃSKI K., Rodowód Piastów śląskich, Kraków 2007.

KAJZER L., Zamki i dwory obronne w Polsce centralnej, Warszawa 2004.

KAJZER L., KOŁODZIEJSKI S., SALM J., Leksykon zamków w Polsce, Warszawa 2012.

KAJZER L., Zamki i dwory obronne w Polsce centralnej, Warszawa 2004.

KIRYK F., Nauk przemożnych perła, Kraków 1986. 
KIRYK F., Wielki król i jego następca, Kraków 1992.

KLUBÓWNA A., Ostatni z wielkich Piastów, Warszawa 1982.

MACIEJEWSKI J., NOWAKOWSKI T., Kazimierz Wielki i jego państwo, Bydgoszcz 2011.

O’MALLEY J. W., Historia papieży, tłum. M. Zmuda, Kraków 2010.

ROŻEK M., Groby królewskie na Wawelu, Kraków 2009.

ROŻEK M., Krakowska katedra na Wawelu, Kraków 2010.

ROŻEK M., Polskie insygnia koronacyjne. Symbole władzy państwowej, Kraków 2011.

ROŻEK M., Polskie koronacje i korony, Kraków 1987.

RUTKOWSKI A., Objazdy i system rzadzenia państwem przez Kazimierza Wielkiego, „Kwartalnik Historyczny” 1978, t. 85, nr 3, s. 605-626.

STOPKA K., BANACH A. K., DYBIEC J., Dzieje Uniwersytetu Jagiellońskiego, Kraków 2000.

ŚMIGIEL K., Słownik biograficzny arcybiskupów gnieźnieńskich i prymasów Polski, Poznań 2002.

URUSZCZAK W., Commune incliti Poloniae regni privilegium constitutionum et indultuum. O tytule i mocy prawnej Statutu Łaskiego z 1506 roku, „Zeszyty Naukowe Uniwersytetu Jagiellońskiego. Prace z Prawa Własności Intelektualnej" 2006, t. 96, s. 115-135, http://www.law.uj.edu.pl/users/khpp/statut_laski.htm [dostęp: 27.10.2015].

WINDAKIEWICZ S., Dzieje Wawelu, Kraków 1925.

WYROZUMSKI J., Dzieje Krakowa. Kraków do schyłku wieków średnich, t. 1, Kraków 1992.

WYROZUMSKI J., Kazimierz Wielki, Wrocław 2004.

ZANIEWSKI P. A., Zamki Kazimierza Wielkiego, Kraków 2012. 